\title{
PUBLIC DIPLOMACY AND COOPERATION WITH NON-GOVERNMENTAL ORGANIZATIONS IN THE LIBERAL PERSPECTIVE OF INTERNATIONAL RELATIONS
}

\author{
NATALIA BROŚ \\ Faculty of Social Sciences, University of Wroclaw, \\ ul. Koszarowa 3, Wroclaw, Poland \\ E-mail address: natalia.bros@gmail.com
}

\begin{abstract}
This article discusses the issue of state cooperation with non-governmental organizations in public diplomacy. This has been explored in relation to the liberal perspective in international relations, which very clearly highlights the importance of NGOs as an influential participant in world politics. The article contains an analysis of the international system, categorizes the roles and functions of NGOs in international relations. It shows concepts of contemporary understanding of power and a clear focus on reinforcing and using components of soft power, including public diplomacy, in modern international relations. Methodological aspects are deepened by an analytical layer exploring Civil Society 2.0 Program, which is an example of an effective combination of diplomatic efforts between the state and NGOs to achieve common goals.
\end{abstract}

Key words: Liberalism, public diplomacy, NGO, soft power, Civil Society

Liberal institutionalists recognize that understanding and explanation of international relations only across the categories of power and interests of the countries is inadequate in the modern world because it does not reflect to reality in the era of globalization. Neoliberal theory assumes that not only the states, which still remain key actors who are developing world order, but also non-state (non-territorial) participants are a key element influencing the shape of contemporary international relations. Recognizing the increase of interdependence between countries, intensification of the integration processes, neoliberals consider that power, defined by Joseph Nye as the ability to affect others to obtain the outcomes you want have changed and dissipated dramatically (Nye, 2012).

The 1970s brought intensive development of the number of international organizations, both governmental and non-governmental. The growing importance of non-state actors causes contestation of the realist paradigm in which highlighting of state exclusiveness - as an actor in international relations, stands at the centre of the theory (Moravcsik, 1997). Researchers deri- 
ved from liberalism, observing transformation of the international structure of political power, proposed to supplement the list of key global actors of the international and transnational organizations (inter- and non-governmental). Changes in the international system also affected the sphere of diplomacy, which currently took the form of a new public diplomacy, in which significant role is attributed to non-state actors, especially non-governmental organizations (Gilboya, 2001).

The present article focuses on the characterization of the international system captured by the liberal perspective, emphasizing the importance of non-territorial actors in international relations. It analyzes the relationship between the state and non-governmental organizations, especially in the public diplomacy area, underlining their correlation and mutual conditioning in achieving the objectives of transnational politics.

\section{INTERNATIONAL RELATIONS IN PERSPECTIVE OF LIBERAL THEORY}

In the liberal paradigm the international system is explained by three general concepts. The first one recognizes the system not as a structure, but as process in which numerous interactions occur between the parties, and each of the parties, involved in that exchange, comes under transformations forced by inferring and learning from the other actors involved. Liberal theory assumes that the main participants of the political processes are states, international organizations (both governmental and non-governmental), multinational corporations, etc. The result of this such complex system of entities and relationship between them, is to understanding and defining of the international system through national interests (Mingst, 2006, p. 86). Liberalism, although not as significantly as realism, examines the category of security interest. But in contrast to realism, liberalism treats the above categorisation as being more complex, because it includes economic or social matters to the agenda of the phenomena associated with security interest. The concept of Robert Keohane and Joseph Nye describes the international system as a system of interior relations, assumes that the relationships between the actors run by variety channels which connect states, their elites, but also international organizations (governmental and non-governmental) (Keohane, \& Nye, 2011).

The second concept of the international system in terms of liberal theory is closely linked with the English tradition of international society understanding. Some of its major thinkers, Adam Watson and Hedley Bul, indicate that however international system is a group of independent political communities, international community is something more than that. International community "not merely forms a system, in the sense that the behaviour of each is a necessary factor in the calculations of the others, but has also established a dialogue and consent common rules and institutions for conduct of their relations, and recognition of their common interest in maintaining these arrangements" 
(Bull, \& Watson, 1984, p. 64). In this sense, the liberal international system is the forum for the positive interaction between system participants.

The third concept of the international system is represented by the neo-liberal institutionalists. They claim, like the realists, that international relations are anachronistic, and that the states - in their activities, are guided by self-interest (Keohane, \& Martin, 1995). However, in contrast to the concept of the realistic, neo-liberals notice potential positive results of interactions or relations between involved parties which might occur and take the form of appointing organizations, international institutions, whose powers allow regulation of the relations between the actors involved.

This anachronistic system, understood as the absence of transnational government which would be able to regulate international relations, according to liberal theory "does not necessarily imply a system of self-reliance or self-help, but it can produce a cooperative basis" (Czaputowicz, 2007, p. 215). Furthermore self-limitation of countries visible through providing part of the powers to the international organizations is a sign of building a compromise in which states shall take into account the interests of other participants involved in international relations issues. In contrast to the realism, the liberal perspective assumes that instead of security matters, welfare of the people seen in economic, social terms, is the overriding objective of state policy. Thus the hard power has give way to the soft power or smart power, which allows the building of the power of the state (Nye, 2012).

Focusing on the study of the complexity and diversity which occur in the global or transnational relations, Keohane and Nye observe the occurrence of an interdependence complex between the actors of international relations, which implies the possibility of simultaneous existence of conflict and competition as well as the occurrence of a win-win cooperation (Keohane, \& Nye, 2001). "From the analysis, complex interdependence is characterized by three characteristics, involving (1) the use of multiple channels of action between societies in interstate, transgovernmental, and transnational relations, (2) the absence of a hierarchy of issues with changing agendas and linkages between issues prioritized and the objective of (3) bringing about a decline in the use of military force and coercive power in international relations" (Keohane, \& Nye, 2001, p. 115). Among others this relationship is characterized by multiplicity of communication channels and also by the low impact of military force which could be used as a component to conduct policy. Complex interdependence implies that achieving political goals is possible not only through the use of force, and through the "'merger cases, the use of asymmetric interdependence, international organizations and transnational actors" (Keohane, \& Nye, 2001, p. 120).

In liberal opinion, the international system, understood as a process, is characterized by constant changes within its structure- involved actors. Its transformation is derived from several factors. Liberals point to the impact of technological progress (an external phenomenon in which involved participants do not have any effect) on the increasingly progressive interdependence between all members of the system. Another reason for the change is the appearance 
of new actors in international relations, i.e. government organizations, NGOs, transnational corporations, whose activities are changing the current role of the state and, consequently, the entire structure of the international system.

\section{NGOs}

Within recent decades non-governmental organizations came to be seen as influential participants in world politics. Their position in international relations is not only the result of intensive growth in the number of NGOs which are involved in transnational issues, but also is upshot of new skills acquisition and development of mechanisms to be able to effectively achieve their goals. An NGO is defined as non-profit, voluntary citizens' group which is organized on a local, national or international level (Popiuk-Rysińska, 2006). Task-oriented and driven by people with a common interest, NGOs perform a variety of service and humanitarian functions, bring citizen concerns to Governments, advocate and monitor policies and encourage political participation through provision of information. Non-governmental organizations are characterized by great diversity, among them common organizations active at the international, regional organizations or local. Membership in them may be general, mass, or elitist, exclusive and limited to clearly defined environments. Differentiation of the organization had impact on their naming convention or categorization, but the "NGO" still remains as the common core naming. The conglomerate of these organizations can be distinguished: GONGO (government-organized NGOs) or NGOs whose founders are governments, BINGO (business and industry NGOs) - established by a group associated with business and industry, DONGO (donor-organized NGO) - appointed by the donors, ONGO (operational NGO) known as operating NGOs (Boli, \& Thomas, 1997).

The growing importance and influence of NGOs is clearly observed since the beginning of the 70s. There was a period not only of significant increase in the number of organizations but also of the development of cooperation between them, including agreements. Increase in their activity, seen as effective mobilization of the general public and thus influence on international relations, was derived from multiple overlapping factors. The global discourse on contemporary problems and threats has certainly caused change in the states and international community perception. Topics taken by the NGOs began to be seen as transnational phenomena (climate change, terrorism and organized crime, pollution, disease etc.), which require coordinated cooperation in order to overcome them. The next stage of strengthening the position of NGOs was the conclusion of agreements between them, which would build a global coalition of social movements with the greatest competence and ability to influence the shape and direction of international relations (Davies, 2014). The next stage of strengthening the position of NGOs was the conclusion of agreements between them, which aimed at creation of global coalition of social 
movements with the greatest competence and ability to influence the shape and direction of international relations. The increase in the number of NGOs can be explained also by the communication revolution and its effects, such as creation of the Internet, which enabled NGOs to communicate with partners and key customers, also to inform about their actions and demands an international audience, to build their image and social trust, and ultimately to obtain mass support for their actions.

\section{ROLES AND FUNCTIONS OF NON-GOVERNMENTAL ORGANIZATIONS}

One of the key roles performed by the NGOs is to act as pressure groups focused on promoting specific values by, among others, new projects and international regulations. In addition, they try to enforce other actors in the international system to respect standards - both formal (named in international law) and informal, related to human rights, environmental protection, etc. NGOs act as observers and initiators of change in listed areas, furthermore their educational and informative activities are based on dissemination of information, publication of research results, organizing international action in the form of rallies, demonstrations which are planned to mobilize public support or to defend certain values or groups (Moron, 2015). By making public and highlighting the importance of transnational issues, non-governmental organizations enforce discussion on both individual countries and at the international level. In case of failed states, where the government does not perform their duties, NGOs fulfill a very important function especially at local or national level because non-governmental organizations often take over government roles in the areas of education, health care or humanitarian aid. In many instances where governmental and private services do not or cannot meet all the needs of their constituents, civil society organizations endeavour to fill the gaps. For this purpose, they establish cooperation with other organizations or countries, going into the role of the body responsible for the conducting of diplomacy (Lyal, \& Sunga, 2005).

Through their political independence from the state, non-governmental organizations can run their own international policy at all stages of its creation (formulation of objectives, policies, decision-making, implementation) (Stillman, 2007). Their power of influence is manifested by influencing the behaviour of countries by initiating formal actions, with basis in law, that must be understood as exerting pressure on the authorities. The versatility and power of influence of NGOs are the result of methods of their conducted operations, which are based on the acquisition and transmission of reliable information and expertise that translates into building their authority among societies and governments. 


\section{THE USE OF NGOS IN PUBLIC DIPLOMACY}

The growing interest and popularity of public diplomacy in recent years must be seen mainly through changes in the functioning of the international relations and also by the arrival of new means of communication in a transnational dimension. Both factors have stimulated widespread recognition as those which has shaped the importance of public diplomacy in the theory and practice of international relations.

Beata Ociepka defines public diplomacy as a form of political communication at the international level, stressing that it is addressed to a wider audience abroad than classical diplomacy. According to the author's definition public diplomacy is a "form of bilateral political dialogue in international communication, addressed to the foreign audience, realized through the mediation of the media and through direct channels. Its goal is to shape - by influencing public opinion - positive attitudes towards the country, which steers the message" (Ociepka, 2008, p. 12). This way of understanding public diplomacy highlights its supporting role in shaping foreign policy, since public diplomacy serves and is intended to facilitate the political objectives of a particular country in the international environment.

The brand and image of the country are one of the key elements comprised within the meaning of public diplomacy itself. Józef Kukułka's theory of international perceptions context claims that "images are an important factor in determining the ability to achieve foreign policy goals" (Kukułka, 1992, p. 94). Within the outlined image, being a category of public diplomacy supports the realization of national goals by building acceptance of the international environment for its policies, strategies, specific activities and projects, as well as its interests.

The new shape of the international environment, where countries are no longer sole participants in a relationship, had an impact also on the entities which are involved in the creation of public diplomacy. Being one of the elements of political communication at the international level, public diplomacy is conducted by governments - in the formula governments to people (G2P), and also by non-governmental organizations and other participants of international relations, who have an influence on state image - in the formula people to people (P2P) (Taylor, 2009). According to Beata Ociepka "diplomacy, in its classic version is reserved only for governments, is changing by opening it to the public - citizens (...), who are at the same time actors and recipients of public diplomacy" (Ociepka, 2013, p. 81). The new shape of international relations forces the usage of new methods of image building, goal achievement communicating and getting messages to recipients. Governments and their agencies are no longer the sole bodies which are considered as a conveyor belt in the diplomacy processes, but also non-governmental organizations, which, through their international authority, as well as the means and methods, which can not be used by official government agencies, are increasingly visible as the mentioned conveyor belt. NGOs are able to shape their own message and sta- 
tement, independent of the governments, which reach to a wide international audience.

NGOs as organizations enjoy a widespread recognition by the state, as well as leaders who take care of the state and civil society development in the local and global scale, as practice shows are included in the public diplomacy circles in two dimensions. The first one, associated with the country of origin of a particular NGO, characterized by recognition of non-governmental organizations as part of the resources of the state soft power. It corresponds to the modern shape of international relations, in which non-state actors play an important role, as well as the theory of the new public diplomacy which emphasizes inter alia, their importance in the country's foreign policy shaping. In addition NGOs as part of public diplomacy conduct social diplomacy which is addressed outside country. The effectiveness and scope of the activities of aid organizations also reflect the image and brand of the country, as it is here "the effect of the country of origin" (Maheswaran, 2008). Inclusion of non-governmental organizations to the state's public diplomacy is also achieved by giving them the role of advisory, expert or consulting bodies for the Ministry of Foreign Affairs (Grant, 2004). They participate in official meetings, provide an opinion on the projects or official documents, complement the government speeches or statements in the field of international cooperation in the area of development assistance, humanitarian, cultural exchange, business and so on.

The second model assumes the inclusion of NGOs of interest to the public diplomacy of the third country. The relationship between NGOs and the third country is found in several variants. Government building its public diplomacy, can enable NGOs in its structure as a foreign partner organization and thus outside of the state jurisdiction. This inclusion tends to take the form of financial, media, legal, technological support. The core of the cooperation is to achieve the mutual benefit of both sides, in case of state is to build lasting relationships with NGOs, getting a partner outside the country, whose confidence and strong position in civil society reflects into building a positive image of the country which supports the society, which is one of the main objectives of public diplomacy (Edwards, \& Hulme, 2002). The state - the partner is seen by the citizens of the country as an active entity engaged in the situation of NGOs, and thus as an actor working to improve the situation of these citizens. With the power of attraction and the ability to shape public opinion by an NGO, the image of the supporting state, as well as favour to it can be significantly improved in the country of origin of NGOs. Non-governmental organizations, depending on the state system and its legitimacy in the politics of the country, can have an impact also on the national government and thus affect its relations with a third country which is involved in NGOs support. The NGO thanks to the cooperation can gain access to new funding or information sources. External assistance may result in, among others, the inclusion of NGOs in the partner network of other organizations which are acting for the third sector matters, which translates into strengthening its role and importance both in the country and abroad. International cooperation is an opportunity for NGOs 
to engage in projects and assistance programs on a larger scale, and also to strengthen and emphasize the problems which afflict the country on whose territory the organization operates. A partner country may also serve a protective function in relation to the NGOs (recognized as the representative of society), especially if the NGO comes from a country with an undemocratic political system, in which the activities of NGOs are limited or prohibited by the government and law. Cooperation, however, carries the risk of dependence on the state-partner, both in financial and political terms, and thus may bring to an NGO the opinion of being an agent or spy who works for the benefits of a foreign country. From the perspective of the state which supports the NGO, aid may result in a deterioration of relations with the origin country of organization because of its involvement and can be seen as an foreign intervention in the interests of the other country and interfering in its internal politics.

\section{CIVIL SOCIETY 2.0 AND TECHCAMPS PROGRAMS}

The United States as one of the first countries has recognized the importance of soft power in international relations. After the events of 9/11 or military involvement in the Middle East, the United States, wanting to regain a positive image in the international arena, had to reorganize their diplomatic activities. The means of image reconstruction became components of the new public diplomacy area, which permanently etched into the action model used by the U.S. Department of State. The United States as a global power aims at selecting its economic or political commitment in all regions of the world. Upon the realization that basing only on government diplomatic measures is an inadequate approach in the current international situation and that inclusion of non-government actors to the group of supporters for its foreign policy is currently absolutely required. The inadequacy and ineffectiveness of this part of US diplomacy which is based only on the government structure, results from the fact that many countries perceive US actions as a new form of cultural imperialism, and see them as the next step in building the hegemonic position of the United States - at the expense of states with less potential or power (Rasmussen, 2012). Using the solutions suggested by the new public diplomacy researchers, as well as observing the changing shape of international relations, in which non-state actors have become one of the actors in the international balance of power, the U.S. Department of State has recognized non-governmental organizations as key partners in achieving the objectives of US foreign policy. NGOs, both located inside and outside of the US, through their activities help to build a positive image of the US, and often sharing the American point of view on human rights protection, environmental matters, they are able to support the realization of the US government vision of a world in which democracy and liberal values are the key categories spoken by the US in foreign policy.

Supporting the development of NGOs and building a network of civil society is a long-term goal of the U.S. Department of State. According to the US diplo- 
matic agenda "Civil society is instrumental in the advancement of democracy, transparency, respect for human rights and good governance; it makes communities more prosperous and stable, encourages mutually sustainable economic growth and pushes political institutions to be agile and responsive to the people they serve" (Dowd, 2011). During the speech in Marrakech in 2009 Hilary Clinton stated "As the world evolves and technology is increasingly used to build and sustain social networks and avenues for communication, we recognize that it is critical to ensure that all civil society organizations can use these new tools to advance their missions in the 21st century". Drawing on the experience of the methods developed for the program 21st Century Statecraft, the United States has decided to use technological solutions to strengthen the competence of non-governmental organizations, thus expanding the scope of US public diplomacy - moving from the communication between national governments (G2G), to engage the actions of the international community (G2P). Implementation of policies to support civil society, to ensure that even the smallest civil society organization can access and use connection technologies - to build the capacity of NGOs using new technologies, was the announcement by the then Secretary of State Hillary Clinton, the Civil Society 2.0 initiative in Marrakech, Morocco, in 2009. She mentioned: "Civil Society 2.0 is designed to help small organizations that work for the social good to increase their capabilities by using connection technologies. The goal is to create a long-term, self-sustaining network of technologists, volunteers and civil society advocates dedicated to promoting the work of civil society in the 21st century" (Clinton, 2009).

An example of realization of the Civil Society 2.0 objectives is TechCamp initiative - a series of interactive conferences held regularly in different parts of the world, gathering more than 1,130 organizations from 81 countries. TechCamps are a key element of the initiative for the development of civil society 2.0 hosted in the bureau of International Information Programs (IIP) at the U.S. State Department and partnership NGOs or private companies. TechCamps are described as "a diplomatic tool used by the U.S. State Department, to engage/empower specific groups like (civil society organizations, journalists, entrepreneurs and government representatives), by training them in the use of low-cost, easy-to-implement technological tools/concepts, making these groups more effective in the work they do" (US Department of State). Entities who are involved in TechCamps building underlie common goals: focusing on liberal values, which should include the promotion of human rights - including freedom of speech, press and assembly in cyberspace, equality of access to knowledge and technology, as well as activities for the opening of markets for digital goods and services in order to promote innovation, and investment.

The aim of the conference is to build civil society in the 2.0 formula. The vision of this initiative is based on the creation of technical possibilities to organize civil society, which could carry out their tasks through the use of technology, particularly via the Internet (examples include how to build a website, engage in social media, develop a mobile application). Two-day events are based on conducting practical training with technology experts and on-the- 
-ground civil society practitioners, during which experts from the IT work directly with local and regional NGOs to match the technology to the needs and problems of a particular NGO - to harness the latest connection technologies and further the goals of their mission. The result of training, lectures and individual or group meetings, hands-on training and interaction is to create technical - digital tools dedicated to NGOs, which will be helpful in their daily activities, as well as help them to increase their digital competences and strengthen networks with other NGOs. The first edition of that interactive conference took place in 2010. So far 46 TechCamp meetings have been held during which over 2,300 people from 110 countries were trained. The number of participants during each edition varies between 40 and 150 people, where the ratio between experts and representatives of NGOs is 30\% to $70 \%$.

Despite the diversity of actors, organizations participating in TechCamps their specific requirements, operating conditions, available expertise, interactive conferences is concentrated around six general topics: human rights, environment, youth empowerment, open government, media/journalism, women's entrepreneurship. The subject of each edition is selected individually by the organizer of the conference and it is adapted to the needs and expectations of NGOs of a particular country or region. Not only the subject, but also the selection of experts is a derivative of a place which visits TechCamps. A group of consultants is chosen in terms of knowledge about the cultural, political, social, economic issues of the country which hosts TechCamp. Traditional TechCamp is initiated by the Office of International Information Programs. U.S State Department provides organizational responsibility at every stage of the functioning of the conference - planning events, analyzing the needs of local communities, selecting experts, budget planning, providing media promotion of conferences, inviting and registering NGOs interested in participating in the conference. The Department is the sole owner of the TechCamp brand, but it allows organizational independence of other entities that are interested in carrying out the event. "Citizens" equivalents of the conferences, not carried out entirely by specialized agencies of the US diplomacy, are called TechCampBox, in which the extent of participation of the Bureau of International Information Programs depends on the organizational capabilities of external stakeholders. TechCampBox must strictly comply with the requirements posed by the State Department and needs to be implemented by conference organizers.

The objective of TechCamp is to encourage civil society participants to reflect upon the most pressing challenges they face in their everyday work, brainstorm ideas with technologists and co-create solutions on the spot. This way of supporting civil society, by developing their digital skills to increase their range of activities, is a reflection of one of the main slogans of American public diplomacy. The US wants to support civil society through real, direct actions and profiled solutions to bring the global reach of initiatives led by NGOs (Mathews, 1997, pp. 56-67). That reality is perceived by categories such as: usability, functionality, mediality, adaptation to the conditions and requirements of society in the 21st century. 


\section{SUMMARY}

States being aware of the growing importance of soft power use it to build their international position, and increasingly more significant impact of new actors shaping the international system, they began to use more diversified measures, which increase their importance in international relations. The United States as one of the first contries has joined NGOs to the circle of its diplomatic activity, giving them a special role in development of the US public diplomacy. This article describes the relationship between the liberal theories of international relations and diplomatic practice undertaken by the global power, in which the use and support of NGOs is one of the key programs for the country's diplomatic potential development. Case Study of TechCamps conference is designed to complement the theory, which highlights the contemporary role played by non-governmental organizations, with the practice of cooperation and interaction between the US and non-governmental organizations. NGOs are part of American diplomacy and support its strategic goals to achieve national interests through soft power. TechCamps meetings support the development of civil society represented by international and local NGOs. They are also a factor in the creation of public diplomacy by engagement in building stability in a particular region. Moreover, they disseminate democratic values through the development of civil society, which is part of the promotion of economic growth and transparency in the countries interested in the TechCamps idea. United States diplomacy is engaged in supporting democracy in the world, thereby realizing their vision of creating a democratic order in international relations respecting the importance of the third sector. Means of realizing this vision is to create a network of partner organizations around the world whose favour guarantees the positive reception of the US in the international arena, also building international credibility of the country, to strengthen its soft power components, as well as amplify the voice of the US government in the world, serving the realization of its vital interests and goals at a global level.

\section{REFERENCES}

[1] Boli, J., \& Thomas, G. M. (1997). World Culture in the World Polity: A century of International Non-Governmental Organization. American Sociological Review, 62 (2),

[2] $171-190$.

[3] Bull, H., \& Watson, A. (1984). The Expansion of International Society. New York: Oxford University Press.

[4] Clinton, H. (2009). Remarks at the Forum for the Future Speech. Marrakech, Morocco. Retrieved December 15, 2016 from https:/ /2009-2017.state.gov/secretary/20092013clinton/ $\mathrm{rm} / 2009 \mathrm{a} / 11 / 131236 . \mathrm{htm}$

[5] Czaputowicz, J. (2007). Teorie stosunków międzynarodowych. Krytyka i systematyzacja [Theories of international relations. Criticism and systematization]. Warszawa: Wydawnictwo Naukowe PWN.

[6] Davies, T. (2014). NGOs: A New History of Transnational Civil Society. New York: Oxford University Press. 
[7] Dowd, K. (2001). Civil Society 2.0. E-Journal USA. U.S. Department of State, Volume 16, Number 3, 1-48. Retrieved December 20, 2016 from http://photos.state.gov/libraries/ amgov/30145/publications-english/Cultivating_Civil_Society_Volume_16\%20_Number_3. pdf

[8] Edwards, M., \& Hulme, D. (2002). Making a difference: NGOs and development in a changing world. London: Earthscan Publications Ltd.

[9] Gilboa, E. (2001). Diplomacy in the media age. Three models of uses and effects. Diplomacy \& Statecraft, 12(2), 1-28. doi: 10.1080/09592290108406201.

[10] Grant, R. (2004). The democratisation of diplomacy: negotiating with the Internet. Oxford Internet Institute, Research Report, No. 5, 1-48. Retrieved November 19, 2016 from https:/ / www.oii.ox.ac.uk/archive/downloads/publications/RR5.pdf.

[11] Keohane, R., \& Martin, L. L. (1995). The Promise of Institutionalist Theory. International Security, Vol. 20, No. 1, 39-51.

[12] Keohane, R. O., \& Nye, J. (2001). Power and Independence. World Politics in Transition. New York: Longman.

[13] Kukułka, J. (1992). Postrzeganie międzynarodowe [International perception]. Stosunki Międzynarodowe, t. 16, 1992, 91-105.

[14] Maheswaran, D. (2008). Nation Equity: Country-of-Origin Effects and Globalization. New York University. Retrieved from http://www.nationequityresearch.com/Handbook_COO_ Chapter_7-0308.pdf

[15] Mathews, J. T. (1997). Power Shift. Foreign Affairs. Retrieved from https://www.foreignaffairs.com/articles/1997-01-01/power-shift

[16] Mingst, K. (2006). Podstawy stosunków międzynarodowych [Essentials of International Relations]. Warszawa: Wydawnictwo Naukowe PWN.

[17] Moravcsik, A. (1997). Taking Preferences Seriously: A Liberal Theory of International Politics. International Organization, Volume 51, Issue 04, 523-527.

[18] Moroń, D. (2012). Organizacje pozarządowe: fundament społeczeństwa obywatelskiego [Non-governmental organizations: the foundations of civil society]. Wrocław: Wydawnictwo Uniwersytetu Wrocławskiego.

[19] Nye, J. (2012). Przyszłość siły [The Future of Power]. Warszawa: Wydawnictwo Naukowe PWN.

[20] Ociepka, B. (2008). Dyplomacja publiczna [Public Diplomacy]. Wrocław: Wydawnictwo Uniwersytetu Wrocławskiego.

[21] Ociepka, B. (2013). Miękka siła. Dyplomacja publiczna Polski [Soft Power. Public Diplomacy of Poland]. Warszawa: Wydawnictwo Naukowe Scholar.

[22] Popiuk - Rysińska, I. (2006). Uczestnicy stosunków międzynarodowych, ich interesy i oddziaływania [Participants in international relations, their interests and influences]. In: E. Haliżak, R. Kuźniar (Eds.) Stosunki międzynarodowe. Geneza, struktura, dynamika [International relations. Genesis, structure, dynamics]. Warszawa: Wydawnictwo Uniwersytetu Warszawskiego.

[23] Rasmussen, I. W. (2012). Towards a Theory of Public Diplomacy. A quantitative study of public diplomacy and soft power. The Fletcher School (Tufts University). Retrieved from http:/ / sites.tufts.edu/ivanwr/files/2012/06/ A-Theory-of-Public-Diplomacy-RasmussenJune-2012.pdf

[24] Stillman, G. B. (2007). Global Standard NGOs: The Essential Elements of Good Practice. Geneva: Lulu Books.

[25] Sunga, L. S. (2005). NGO Involvement in International Human Rights Monitoring, in International Human Rights Law and Non-Governmental Organizations. Brussel: Bruylant.

[26] Taylor, P. M. (2009). Public Diplomacy and Strategic Communications. In: N. Snow, P. M. Taylor (Eds.) Routledge Handbook of Public Diplomacy. New York: Routledge.

[27] U.S. Department of State. (n.d.). Civil Society. Retrieved November 10, 2016 from http:// www.state.gov/statecraft/cs20/index.htm 